DOI: 10.19112/2413-6174-2021-S1-22

\title{
ОБОГАЩЕНИЕ ПРОДУКТОВ ХЛЕБОПЕКАРНОГО ПРОИЗВОДСТВА БИОЭЛЕМЕНТАМИ
}

\author{
П.В. Медведев, В.А. Федотов * \\ Оренбургский государственный университет, 460013 г. Оренбург, пр. Победы 13 \\ *e-mail: vital_asm@mail.ru
}

РЕЗЮМЕ. Проведено исследование качества дрожжевых полуфабрикатов, приготовляемых с использованием солевых растворов наиболее дефицитных для человека биоэлементов. Жизнеспособность дрожжей из семейства сахаромицетов Saccharomyces cerevisiae оценивали по показателю подъемной силы (контроль $50 \pm 2$ мин при температуре $\left.35 \pm 2{ }^{\circ} \mathrm{C}\right)$. Замена в тестовых образцах $(n=30)$ поваренной соли $(2,5 \% \mathrm{NaCl})$ на сульфаты меди, цинка $(\mathrm{XЧ} \mathrm{Cu}, \mathrm{Zn})$ эквимолярной концентрации $(0,42$ моль/л) приводила к снижению подъемной силы не более чем на $5 \%$, на сульфат марганца (ХЧ Mn) - не более чем на 9,5\% ( $<<0,05)$. Это не приводит к несоответствию качества дрожжевых полуфабрикатов нормативной документации. Дальнейшее увеличение концентрации меди, цинка и марганца вызывает существенное торможение жизнедеятельности дрожжей: при 1,5-кратном увеличении - Сu на $12,5 \%, \mathrm{Zn}$ на 9,5\%, Mn на 15\%; при 2-кратном увеличении - Cu на 18,5\%, Zn на 15\%, Mn на 28,5\%.

КЛЮЧЕВЫЕ СЛОВА: биоэлементы, дрожжи, обогащение, хлеб.

\section{ENRICHMENT OF BAKERY PRODUCTS WITH BIOELEMENTS}

\author{
P.V. Medvedev, V.A. Fedotov* \\ Orenburg State University, 460013, Orenburg, Pr. Pobedy 13 \\ *e-mail: vital_asm@mail.ru
}

\begin{abstract}
A study of the quality of yeast semi-finished products prepared using salt solutions of the most deficient bioelements for humans was conducted. The viability of yeast from the Saccharomyces cerevisiae family of Saccharomyces was evaluated by the lift index (control $50 \pm 2 \mathrm{~min}$ at a temperature of $35 \pm 2{ }^{\circ} \mathrm{C}$ ). The replacement of table salt $(2.5 \% \mathrm{NaCl}$ ) in the test samples $(n=30)$ with copper and zinc sulfates $(\mathrm{Cu}, \mathrm{Zn})$ of equimolar concentration $(0.42 \mathrm{~mol} / \mathrm{l})$ led to a decrease in the lifting force of no more than $5 \%$, and manganese sulfate $(\mathrm{Mn})$ of no more than $9.5 \%(p<0.05)$. This does not lead to noncompliance of the quality of yeast semi-finished products with the regulatory documentation. A further increase in the concentration of copper, zinc and manganese causes a significant inhibition of the vital activity of yeast. With a 1.5-fold increase of $\mathrm{Cu}$ by $12.5 \%, \mathrm{Zn}$ by $9.5 \%, \mathrm{Mn}$ by $15 \%$. With a 2 -fold increase of $\mathrm{Cu}$ by $18.5 \%$, $\mathrm{Zn}$ by $15 \%$, Mn by $28.5 \%$.
\end{abstract}

KEYWORDS: bioelements, yeast, fortification, bread.

\section{ВВЕДЕНИЕ}

Традиционно для подкормки дрожжевых культур используют соли аммиака, которые легко ими потребляются, и аминокислоты как продукты гидролиза белка пептазами (Chung, et al. 2003). Помимо этого, для нормального метаболизма необходимы микроэлементы, которыми часто пренебрегают, поскольку они требуются в незначительных количествах. Однако насыщение полуфабрикатов хлебопекарного производства (опары, закваски) микроэлементами может служить одним из путей обогащения ими производимой продукции - хлеба и хлебобулочных изделий (Maningat, et al. 2009). Анализ источников литературы выявил, что на территории Российской Федерации приоритетна проблема дефицита меди, цинка, марганца (Kozub, et al. 2009).

Цель работы - изучить возможности обогащения полуфабрикатов хлебопекарного производства биоэлементами в процессе культивации дрожжевых культур.

\section{МАТЕРИАЛЫ И МЕТОДЫ}

Материалом служили прессованные дрожжи из семейства сахаромицетов Saccharomyces cerevisiae c влажностью не более $75 \pm 1 \%$, подъемная сила - не более $50 \pm 2$ мин. Изучаемые элементы вводились в виде растворов сульфатов меди, цинка, марганца (ХЧ $\mathrm{Cu}, \mathrm{Zn}, \mathrm{Mn})$. Bсе вещества хорошо растворимы в 
воде, образуют с ней кристаллогидраты. Жизнеспособность дрожжей оценивали по показателю «подъемная сила». Подъемную силу определяли по продолжительности, в минутах, с момента опускания тестового образца в емкость до его всплытия, умножали на коэффициент 3,5 (при температуре $35 \pm 2{ }^{\circ} \mathrm{C}$ ). Для оценки воздействия солей биоэлементов на жизнестойкость дрожжей поваренную соль (хлористый натрий) в тесте заменяли количеством солей меди, цинка, марганца с той же молярной концентрацией (эквимолярное количество) или превышающей эту концентрацию в 1,5 и 2 раза $(n=30)$.

\section{РЕЗУЛЬТАТЫ И ОБСУЖДЕНИЕ}

Оценивали развитие дрожжей на питательной среде с добавкой солей меди, цинка, марганца. Использование солей меди и цинка при их концентрации, эквимолярной натрию хлориду $(0,42$ моль/л), что соответствует массовой доле $\mathrm{NaCl}$ в тестовом образце 2,5\%, не вызывает ухудшения подъемной силы дрожжей, приводящей к несоответствию качества полуфабрикатов нормативной документации (снижение подъемной силы не более 5\%). Использование солей марганца той же концентрации снижает подъемную силу на 9,5\% (p<0,05). При дальнейшем повышении дозировки солей набдюдалось угнетение роста дрожжевой культуры. Существенное торможение жизнедеятельности дрожжей вызывает 1,5-кратное увеличение эквимолярной концентрации $\mathrm{Cu}$ - подъемная сила снижается на $12,5 \%, \mathrm{Zn}$ - на 9,5\%, Mn - на $15 \%$ ( $p<0,05)$, при 2-кратном увеличении: $\mathrm{Cu}$ - на $18,5 \%, \mathrm{Zn}$ - на 15\%, Mn на $28,5 \%(p<0,05)$.

\section{ВЫВОДЫ}

Проведенные исследования доказывают возможность использования биоэлементов для обогащения продукции хлебопекарного производства при соблюдении соответствующих дозировок солей этих биоэлементов, существенно не нарушающих процесс культивации дрожжевых клеток Saccharomyces cerevisiae в хлебопекарных полуфабрикатах.

\section{Список литературы / References}

1. Chung O.K., Ohm J.B., Lookhart G.L., Bruns R.F. Quality characteristics of hard winter and spring wheats grown under an overwintering condition. J. Cereal Sci. 2003, 37: 91-99.

2. Kozub N.A., Sozinov I.A., Sobko T.A., Sozinov A.A. Variation at storage protein loci in winter common wheat cultivars of the Central Forest-Steppe of Ukraine. Cyt. Genetics. 2009, 43: 69-77.

3. Maningat C.C., Seib P.A., Bassi S.D., Woo K.S., Lasater G.D. Wheat starch: production, properties, modification, and uses. Starch Chem. Technol. 2009, 441-510. 